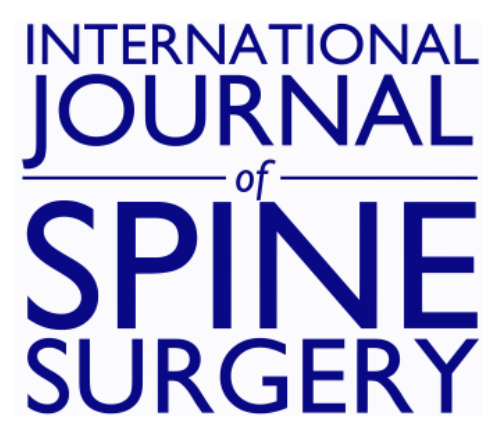

\title{
ISASS Policy Statement - Lumbar Artificial Disc
}

Jack Zigler and Rolando Garcia

Int J Spine Surg 2015, 9 ()

doi: https://doi.org/10.14444/2007

http://ijssurgery.com/content/9/7

This information is current as of April 26, 2023.

Email Alerts Receive free email-alerts when new articles cite this article. Sign up at: http://ijssurgery.com/alerts 


\section{ISASS Policy Statement - Lumbar Artificial Disc}

Jack Zigler, MD, ${ }^{1}$ Rolando Garcia, $M D, M P H$, FAAOS ${ }^{2}$

${ }^{1}$ Texas Back Institute, Plano, TX 2 Orthopedic Care Center, Aventura, FL

\section{Purpose}

The primary goal of this Policy Statement is to educate patients, physicians, medical providers, reviewers, adjustors, case managers, insurers, and all others involved or affected by insurance coverage decisions regarding lumbar disc replacement surgery.

\section{Procedures}

This Policy Statement was developed by a panel of physicians selected by the Board of Directors of ISASS for their expertise and experience with lumbar TDR. The panel's recommendation was entirely based on the best evidencebased scientific research available regarding the safety and effectiveness of lumbar TDR.

KEYWORDS: LUMBAR ARTIFICIAL DISC, LUMBAR ARTHROPLASTY, LUMBAR DISC REPLACEMENT

VOLUME 9 ARTICLE 7 DOI: 10.14444/2007

\section{Background}

Most of the major health insurance carriers in the US, including UnitedHealth, Aetna, Humana, and most Blue Cross Blue Shield affiliates, do not provide coverage for single level lumbar TDR even in patients meeting strict selection criteria. As a result, millions of Americans with chronic and debilitating lumbar degenerative disc disease who might reasonably benefit from a lumbar TDR are denied access to this technology based solely on their insurance carriers coverage policy.

The most common explanation for denying coverage for lumbar TDR is that the technology is considered "experimental and investigational." Some carriers indicate that "the long-term clinical outcome of lumbar disc replacement is unclear. The evidence from uncontrolled long-term studies suggests that potential degeneration of adjacent discs and facets and wear of the polyethylene part of the disc may occur and that, in some cases, revision surgery may be needed." Statements like this are disingenuous, choosing to ignore the long-term outcomes from well-controlled Level 1 studies demonstrating decreased adjacent segment degeneration, minimal component wear issues, and lower revision rates than fusion.

\section{Rationale}

A common definition of an experimental technique is one that is new and untested.

A common definition of an investigational technique is one that is not approved and under investigation in clinical trials.

Evaluation of peer reviewed published literature and publicly-debated scientific presentations provides extensive evidence that lumbar disc replacement is neither experimental nor investigational. It has been extensively tested and has received FDA approval after careful and lengthy evaluation of multicenter Level 1 data. Lumbar TDR is not new. The idea of replacing damaged or degenerated lumbar discs started in the 1950 's. ${ }^{1,2}$

Over the last several decades, multiple attempts have been made to replace painful lumbar disc with implants that maintain motion at the operative level. The Charite artificial disc, developed in Berlin in the 1980s by Drs. Karin Buttner-Janz and Kurt Schellnack was first implanted in the US in 2000 to start a multicenter prospective randomized IDE study. Since 2000, tens of thousands of patients have been treated in the US and worldwide with an increasing inventory of lumbar disc implants. Although some critics speculated that the widespread availability of lumbar TDR would lead to large failure rates and 
high levels of revision, a detailed and unbiased review of the published literature demonstrates otherwise. Most clinicians and scientists agree that the majority of complications associated with lumbar TDR implantation are related to errors in patient selection, deviating from well established inclusion and exclusion criteria (Table 1, Table 2).

In 2005 Blumenthal et $\mathrm{al}^{3}$ published the result of the first prospective, randomized trial comparing lumbar disc replacement with the Charite to ALIF. The study represented the initial US experience with lumbar disc replacement. 375 patients were enrolled in 14 sites across the US. The authors reported lower levels of pain and disability at all follow up intervals between 6 weeks to 24 months. In addition, the disc replacement group reported higher patient satisfaction, and shorter hospital stay compared to the fusion group. The complication rates in both groups were similar for both groups, but the re-operation

Table 1. Inclusion and Exclusion Criteria for ProDisc-L (from the FDA SSEE labelling document).

\begin{tabular}{|c|c|}
\hline Inclusion & Exclusion \\
\hline $\begin{array}{l}\text { Degenerative Disc Disease (DDD) in one vertebral level between L3 and S1. } \\
\text { Diagnosis of DDD requires back and/or leg (radicular pain); and radiographic } \\
\text { confirmation of any } 1 \text { of the following by CT, MRI, discography, plain film, } \\
\text { myelography and/or flexion/extension films: } \\
\text { Instability ( } \geq 3 \mathrm{~mm} \text { translation or } \geq 5^{\circ} \text { angulation; } \\
\text { Decreased disc height }>2 \mathrm{~mm} \text {; } \\
\text { - Scarring/thickening of annulus fibrosis; } \\
\text { - Herniated nucleus pulposus; or } \\
\text { - Vacuum phenomenon } \\
\text { - } \\
\text { - } \text { Faile between } 18 \text { and } 60 \text { years } \\
\text { (40\%) (Interpreted as moderate/severe disability) } \\
\text { Psychosocially, mentally and physically able to fully comply with this proto- } \\
\text { col including adhering to follow-up schedule and } \\
\text { - Signed inform consent }\end{array}$ & $\begin{array}{l}\text { - No more than } 1 \text { vertebral level may have DDD, and all diseased levels must be treat- } \\
\text { ed } \\
\text { medial-lateral and/or } 27 \mathrm{~mm} \text { in the anterior-posterior directions } \\
\text { - } \text { Known allergy to titanium, polyethylene, cobalt, chromium or molybdenum } \\
\text { - Prior fusion surgery at any vertebral level } \\
\text { - } \quad \text { Clinically compromised vertebral bodies at the affected level due to current or past } \\
\text { trauma } \\
\text { - Radiographic confirmation of facet joint disease or degeneration } \\
\text { - Lytic spondylolisthesis or spinal stenosis } \\
\text { - Degenerative spondylolisthesis of grade }>1 \\
\text { - Back or leg pain of unknown etiology } \\
\text { - Osteopenia or osteoporosis: A screening questionnaire for osteoporosis, SCORE } \\
\text { (Simple Calculated Osteoporosis Risk Estimation), will be used to screen patients to de- } \\
\text { termine if a DEXA scan is required. If DEXA is required, exclusion will be defined as a } \\
\text { DEXA bone density measured T score }<-2.5 \text {. } \\
\text { - Paget's disease, osteomalacia or anything other metabolic bone disease (excluding } \\
\text { osteoporosis which is addressed above) } \\
\text { - Morbid obesity defined as a body mass index }>40 \text { or a weight more than } 100 \text { lbs. } \\
\text { over ideal body weight } \\
\text { - Pregnant or interested in becoming pregnant in the next } 3 \text { years } \\
\text { - Active infection - systemic or local } \\
\text { - Taking medication or any drug known to potentially interfere with bone/soft tissue } \\
\text { healing (e.g., steroids) } \\
\text { - Rheumatoid arthritis or other autoimmune disease } \\
\text { - Systemic disease including AIDS, HIV, Hepatitis } \\
\text { - Active malignancy: A patient with a history of any invasive malignancy (except non- } \\
\text { melanoma skin cancer) unless he/she has been treated with curative intent and there has } \\
\text { been no clinical signs or symptoms of the malignancy for at least } 5 \text { years }\end{array}$ \\
\hline
\end{tabular}

Table 2.Indications and Contraindications for ProDisc-L.

Indications for Use

The ProDisc-L Total Disc Replacement is indicated for spinal arthroplasty in skeletally mature patients with degenerative disc disease (DDD) at one level from L3-S1. DDD is defined as discogenic back pain with degeneration of the disc confirmed by patient history and radiographic studies. These DDD patients should have no more than Grade 1 spondylolisthesis at the involved level. Patients receiving the ProDiscL Total Disc Replacement should have failed at least six months of conservative treatment prior to implantation of the ProDisc-L Total Disc Replacement.
Contraindications

The ProDisc-L Total Disc Replacement should not be implanted in patients with the following conditions:

- Active systemic infection or infection localized to the site of implantation - Osteopenia or osteoporosis defined as DEXA bone density measured T-score < $-1.0$

- Bony lumbar spinal stenosis

- Allergy or sensitivity to implant materials (cobalt, chromium, molybdenum, polyethylene, titanium)

- Isolated radicular compression syndromes, especially due to disc herniation

- Pars defect

- Involved vertebral endplate that is dimensionally smaller than $34.5 \mathrm{~mm}$ in the medial-lateral and/or $27 \mathrm{~mm}$ in the anterior-posterior directions

- Clinically compromised vertebral bodies at the affected level due to current or past trauma

- Lytic spondylolisthesis or degenerative spondylolisthesis of grade $>1$ 
rate was significantly lower in the lumbar TDR group compared to the fusion group (5.4\% vs. $9.1 \%)$.

In 2009, Guyer et $\mathrm{al}^{4}$, published the 5 year follow up results of the Charite IDE trial. One hundred and thirty-three randomized patients were evaluated at a minimum of 5 years post index operation. The authors reported that the Charite group had a statistically higher success rate than the ALIF group (58\% vs $51 \% ; \mathrm{p}=0.0359)$. Although there were no significant differences between the 2 groups in terms of ODI, VAS, or SF-36, patient satisfaction and employment status were higher in the Charite group. The re-operation rate at the index level was $8 \%$ for the Charite group and 16\% for the fusion group. The authors concluded that although there were no statistically significant differences between the 2 groups in clinical outcomes, the Charite group demonstrated higher patient satisfaction, higher employment status, and lower re-operation rates, while maintaining motion at the operative level.

Longer term follow-ups at 10 years have been reported in Europe, demonstrating durability of lumbar arthroplasty. Lemaire et $\mathrm{al}^{5}$ reported on 100 Charite patients with minimum 10 year follow-up. Clinically, $62 \%$ had an excellent outcome, $28 \%$ had a good outcome, and only $10 \%$ had a poor outcome. Of the 95 patients eligible to return to work, $91.5 \%$ did so. These outcomes compare favorably with results described in the literature for fusion for lumbar DDD.

David et $\mathrm{ll}^{6}$ reported on 106 Charite patients with mean follow-up of 13.2 years. Clinical outcomes and the rate of return to work were excellent overall. The rate of adjacent level disease requiring operation (2.8\%) compared very favorably with rates of up to $30 \%$ in patients treated with fusion.

In a more recent publication, Zigler et $\mathrm{al}^{7}$ reported the results of the 5 year follow up of the ProDisc-L study. Of the 236 original cohort of patients, $82 \%$ were available for follow up at a minimum of 5 years post-op. Although both groups demonstrated significant improvements in ODI compared to pre op values, the percentage of patients indicating they would have the surgery again was higher in the ProDisc-L group compared to the fusion group ( $82 \%$ vs. $68 \%$ ). In addition, the re-operation at the index level was lower for the ProDisc group versus the fusion group (8\% vs. $12 \%$ ). The authors concluded that although fusion and disc replacement are reasonable alternatives for well selected patients, patients undergoing lumbar disc replacement have higher patient satisfaction and avoid the segmental stiffness associated with fusion.

As a companion article Zigler et $\mathrm{al}^{8}$ also reported on radiographic adjacent level degeneration as measured by independent radiologic analysis. Comparison of adjacent levels preoperatively and 5 years after surgery demonstrated a threefold increase in adjacent level degeneration in patients who randomized to single level 360 fusion over those who randomized to a ProDisc-L implant. Reoperation rates at the adjacent level were twice as high in the post-fusion patients at 5 years.

Although only ProDisc-L is currently FDA approved in the US for commercial use in the lumbar spine, there are several prospective studies published on the clinical and radiographic outcomes of other lumbar arthroplasty implants in the FDA pipeline. Several lumbar implants are used outside the US (OUS) with thousands of patients implanted, but have not yet gone through an IDE approval for sale in the US.

Gornet et $\mathrm{al}^{9}$ published results of the IDE trial using the Maverick metal on metal implant. The study was the largest prospective, randomized trial comparing lumbar TDR to ALIF with a metal cage and BMP. 577 patients were included in this study, including 405 in the TDR group and 172 in the ALIF group. The disc replacement group reported statistically superior outcomes $(\mathrm{p}<0.05)$ at all post-operative evaluations in ODI, back pain, and SF-36. Operative times and blood loss were higher in the Maverick group, whereas device related adverse events were lower in the Maverick group. The authors concluded that they had demonstrated statistical superiority of the Maverick arthroplasty versus fusion on key clinical outcomes including improved physical function, reduced pain, and earlier return to work. Maverick is implanted only OUS. Metal on metal arthroplasty devices are under intense scrutiny by the FDA as well as by the surgeon community. New MOM designs are likely to face an even more strenuous regu- 
latory path in the future.

Sasso et $\mathrm{al}^{10}$ published their results on a metal on metal implant. The study included prospective data from 2 sites in a multicenter trial comparing lumbar TDR with the FlexiCore implant versus circumferential fusion. 67 patients were included in this prospective randomized trial. Operative time, blood loss, and hospital stay were statistically significantly lower in the FlexiCore group. The authors concluded that the FlexiCore compared very favorably to circumferential fusion for the treatment of lumbar DDD unresponsive to conservative treatment. This implant did not complete the FDA approval process.

In addition to US studies regarding patients enrolled in IDE trials, there are several published European studies comparing lumbar TDR to fusion. Skold et $\mathrm{al}^{11}$ reported results of a prospective randomized studies comparing lumbar TDR to fusion. Of the 152 patients included in this study, 80 were randomized to TDR while 72 were assigned to the fusion group. 99\% of the patients were available for follow up at 5 years post-op. At follow up the percentage of patients who were totally pain-free was significantly higher in the TDR group versus the fusion group (38\% vs 15\%; $\mathrm{p}<0.003$ ). The authors also reported better improvement in VAS and ODI in the lumbar TDR group, with no difference in complications or reoperations.

Although not a randomized study, Siepe et $\mathrm{al}^{12}$ reported their prospective outcomes 5 to 10 years after lumbar TDR with the ProDisc-L implant. The authors reported on 181 patients at an average follow up of 7.4 years. The authors reported significant improvements in VAS and ODI at all postoperative follow up stages $(\mathrm{p}<0.0001)$, and concluded that their results demonstrated satisfactory and maintained mid- to long-term clinical results after a mean followup of 7.4 years. The authors stated that the fears of excessive late complications or reoperations following TDR procedures cannot be substantiated with the present data.

\section{Conclusions}

Science in general, and particularly clinical medicine, has evolved from anecdotal and retrospective investigations to more objective, rigorous, and prospective scientific investigation. In the face of strong Level I prospective randomized multicenter studies with long-term follow-up, it is inexcusable that treatment guidelines be directed by personal opinions and business-based decisions. Treatment guidelines should be based on these tested and proven therapeutic algorithms.

Our interpretation and understanding of the efficacy and safety of clinical interventions can only be dictated by well-established evidenced based guidelines.

Scientifically proven techniques and technologies must be accepted for the benefit of appropriate patients. One of the best values of these multiple IDE studies has been to identify the patients who would predictably benefit from lumbar arthroplasty. IDE study inclusion and exclusion criteria should provide an easy avenue for insurance payors to define the patients they can approve for lumbar disc replacement, since the outcomes for these patients should be predictable.

Based on a thorough review of the best available evidence-based scientific literature the International Society for the Advancement of Spine Surgery concludes that lumbar TDR is not new, experimental, or investigational. It is a well-tested technology which should predictably lead to better outcomes and less complications than fusion surgery, as well as a protective effect on adjacent levels.

There is sufficient evidence-based scientific evidence to support the safety and efficacy of single level lumbar TDR for patients meeting well established selection criteria. ISASS would support patient authorization guidelines that mirror the selection criteria from the IDE studies, as long as the device is implanted by a trained experienced spine surgeon.

There are now several long-term prospective and retrospective studies available on lumbar TDR which provide objective evidence regarding their safety and effectiveness. Data from prospective randomized clinical trials have reported consistently low rates of re-operations, and extremely low levels of particulate 
wear debris complications. A list of relevant research is available below.

Based on sound analysis of the scientific literature, the International Society for the Advancement of Spine Surgery recommends universal coverage for single level lumbar TDR in patients meeting the established selection criteria.

\section{References}

1. Hamby WB, Glaser HT. Replacement of spinal intervertebral discs with locally polymerizing methyl methacrylate: Experimental study of effects upon tissues and report of a small clinical series. J Neurosurg 1959;16:311-3.

2. Fernstrom U. Arthroplasty with intercorporal endoprothesis in herniated disc and in painful disc. $A c$ ta Chir Scand Suppl 1966;357:154-9.

3. Blumenthal S, McAfee PC, Guyer RD, et al. A prospective, randomized, multicenter Food and Drug Administration investigational device exemptions study of lumbar total disc replacement with the CHARITE artificial disc versus lumbar fusion: Part i: Evaluation of clinical outcomes. Spine 2005;30:1565-75.

4. Guyer RD, McAfee PC, Banco RJ, et al. Prospective, randomized, multicenter Food and Drug Administration investigational device exemption study of lumbar total disc replacement with the CHARITE artificial disc versus lumbar fusion: Five-year followup. Spine J 2009;9:374-86.

5. Lemaire JP, Carrier H, Sariali el H, et al. Clinical and radiological outcomes with the Charite artificial disc: A 10-year minimum follow-up. J Spinal Disord Tech 2005;18:353-9.

6. David T. Long-term results of one-level lumbar arthroplasty: Minimum 10-year follow-up of the CHARITE artificial disc in 106 patients. Spine 2007;32:661-6.

7. Zigler JE, Delamarter RB. Five-year results of the prospective, randomized, multicenter, Food and Drug Administration investigational device exemption study of the ProDisc-1 total disc replacement versus circumferential arthrodesis for the treatment of single-level degenerative disc disease. $J$ Neurosurg Spine 2012;17:493-501.
8. Zigler JE, Glenn J, Delamarter RB. Five-year adjacent-level degenerative changes in patients with single-level disease treated using lumbar total disc replacement with ProDisc-l versus circumferential fusion. J Neurosurg Spine 2012;17:504-11.

9. Gornet MF, Burkus JK, Dryer RF, et al. Lumbar disc arthroplasty with maverick disc versus standalone interbody fusion: A prospective, randomized, controlled, multicenter Investigational Device Exemption trial. Spine 2011;36:E1600-E11.

10. Sasso RC, Foulk DM, Hahn M. Prospective, randomized trial of metal-on-metal artificial lumbar disc replacement: Initial results for treatment of discogenic pain. Spine 2008;33:123-31.

11. Skold C, Tropp H, Berg S. Five-year follow-up of total disc replacement compared to fusion: A randomized controlled trial. Eur Spine J 2013;22:2288-95.

12. Siepe CJ, Heider F, Wiechert K, et al. Mid- to long-term results of total lumbar disc replacement: A prospective analysis with 5- to 10-year follow-up. Spine J 2014;14:1417-31.

\section{Additional Literature on Lumbar}

\section{Total Disc Replacement}

Aghayev E, Etter C, Barlocher C, et al. Five-year results of lumbar disc prostheses in the SwissSpine registry. Eur Spine J 2014;23:2114-26.

Aghayev E, Henning J, Munting E, et al. Comparative effectiveness research across two spine registries. Eur Spine J 2012;21:1640-7.

Aghayev E, Roder C, Zweig T, et al. Benchmarking in the SwissSpine registry: Results of 52 Dynardi lumbar total disc replacements compared with the data pool of 431 other lumbar disc prostheses. Eur Spine J 2010;19:2190-9.

Alahmadi H, Deutsch H. Outcome of salvage lumbar fusion after lumbar arthroplasty. Asian Spine $J$ 2014;8:13-8.

Auerbach JD, Ballester CM, Hammond F, et al. The effect of implant size and device keel on vertebral compression properties in lumbar total disc replace- 
ment. Spine J 2010;10:333-40.

Auerbach JD, Jones KJ, Milby AH, et al. Segmental contribution toward total lumbar range of motion in disc replacement and fusions: A comparison of operative and adjacent levels. Spine 2009;34:2510-7.

Auerbach JD, Wills BP, McIntosh TC, et al. Evaluation of spinal kinematics following lumbar total disc replacement and circumferential fusion using in vivo fluoroscopy. Spine 2007;32:527-36.

Aunoble S, Donkersloot P, Le Huec JC. Dislocations with intervertebral disc prosthesis: Two case reports. Eur Spine J 2004;13:464-7.

Aunoble S, Meyrat R, Al Sawad Y, et al. Hybrid construct for two levels disc disease in lumbar spine. Eur Spine J 2010;19:290-6.

Austen S, Punt IM, Cleutjens JP, et al. Clinical, radiological, histological and retrieval findings of Activ-L and Mobidisc total disc replacements: A study of two patients. Eur Spine J 2012;21:513-20.

Awe OO, Maltenfort MG, Prasad S, et al. Impact of total disc arthroplasty on the surgical management of lumbar degenerative disc disease: Analysis of the nationwide inpatient sample from 2000 to 2008. Surg Neurol Int 2011;2:139.

Balderston JR, Gertz ZM, McIntosh T, et al. Longterm outcomes of 2-level total disc replacement using ProDisc-L: Nine- to 10-year follow-up. Spine 2014;39:906-10.

Bassani C. Early and late complication in Charité TDR: An anterior revision surgery after 7 years. Argo Spine 2009;21:159-61.

Baxter RM, Macdonald DW, Kurtz SM, et al. Severe impingement of lumbar disc replacements increases the functional biological activity of polyethylene wear debris. J Bone Joint Surg Am 2013;95:e751-9.

Berg S, Tropp H. Results from a randomized controlled study between total disc replacement and fusion compared with results from a spine register.
$S A S$ J 2010;4:68-74.

Berg S, Tullberg T, Branth B, et al. Total disc replacement compared to lumbar fusion: A randomised controlled trial with 2-year follow-up. Eur Spine J 2009;18:1512-9.

Berry MR, Peterson BG, Alander DH. A granulomatous mass surrounding a Maverick total disc replacement causing iliac vein occlusion and spinal stenosis: A case report. J Bone Joint Surg Am 2010;92:1242-5.

Bertagnoli R, Kumar S. Indications for full prosthetic disc arthroplasty: A correlation of clinical outcome against a variety of indications. Eur Spine J 2002;11 Suppl 2:S131-6.

Bertagnoli R, Yue JJ, Fenk-Mayer A, et al. Treatment of symptomatic adjacent-segment degeneration after lumbar fusion with total disc arthroplasty by using the ProDisc prosthesis: A prospective study with 2-year minimum follow up. J Neurosurg Spine 2006;4:91-7.

Bertagnoli R, Yue JJ, Kershaw T, et al. Lumbar total disc arthroplasty utilizing the ProDisc prosthesis in smokers versus nonsmokers: A prospective study with 2-year minimum follow-up. Spine 2006;31:992-7.

Bertagnoli R, Yue JJ, Nanieva R, et al. Lumbar total disc arthroplasty in patients older than 60 years of age: A prospective study of the ProDisc prosthesis with 2-year minimum follow-up period. J Neurosurg Spine 2006;4:85-90.

Bertagnoli R, Yue JJ, Shah RV, et al. The treatment of disabling single-level lumbar discogenic low back pain with total disc arthroplasty utilizing the ProDisc prosthesis: A prospective study with 2-year minimum follow-up. Spine 2005;30:2230-6.

Bertagnoli R, Yue JJ, Shah RV, et al. The treatment of disabling multilevel lumbar discogenic low back pain with total disc arthroplasty utilizing the ProDisc prosthesis: A prospective study with 2-year minimum follow-up. Spine 2005;30:2192-9. 
Bisseling P, Zeilstra DJ, Hol AM, et al. Metal ion levels in patients with a lumbar metal-on-metal total disc replacement: Should we be concerned? J Bone Joint Surg Br 2011;93:949-54.

Blondel B, Tropiano P, Gaudart J, et al. Clinical results of lumbar total disc arthroplasty in accordance with Modic signs, with a 2-year-minimum follow-up. Spine 2011;36:2309-15.

Blondel B, Tropiano P, Gaudart J, et al. Clinical results of total lumbar disc replacement regarding to various aetiologies of the disc degeneration: A study with a 2 years minimal follow-up. Spine 2011;36:E313-E9.

Blumenthal S, Guyer R, Geisler F, et al. The first 18 months following Food and Drug Administration approval of lumbar total disc replacement in the United States: Reported adverse events outside an Investigational Device Exemption study environment. $S A S J$ 2007;1:8-11.

Blumenthal S, McAfee PC, Guyer RD, et al. A prospective, randomized, multicenter Food and Drug Administration investigational device exemptions study of lumbar total disc replacement with the CHARITE artificial disc versus lumbar fusion: Part i: Evaluation of clinical outcomes. Spine 2005;30:1565-75.

Blumenthal SL, Zigler JE, Guyer RD, et al. Longterm evaluation of re-operation rates for lumbar total disc replacement and fusion: Analysis of 1,237 patients. International Society for the Study of the Lumbar Spine. Scottsdale, Arizona, 2013.

Borkowski P, Marek P, Krzesinski G, et al. Finite element analysis of artificial disc with an elastomeric core in the lumbar spine. Acta Bioeng Biomech 2012;14:59-66.

Boss OL, Tomasi SO, Baurle B, et al. Lumbar total disc replacement: Correlation of clinical outcome and radiological parameters. Acta Neurochir (Wien) 2013;155:1923-30.

Botolin S, Puttlitz C, Baldini T, et al. Facet joint bio- mechanics at the treated and adjacent levels after total disc replacement. Spine 2011;36:E27-32.

Buttacavoli FA, Delamarter RB, Kanim LEA. Cost comparison of patients with 3-level artificial total lumbar disc replacements versus $360^{\circ}$ fusion at 3 contiguous lumbar vertebral levels: An analysis of compassionate use at 1 site of the us investigational device exemption clinical trial. $S A S$ J 2010; 4:107-14.

Buttner-Janz K, Guyer RD, Ohnmeiss DD. Indications for lumbar total disc replacement: Selecting the right patient with the right indication for the right total disc Internat J Spine Surg 2015;8:10.14444/1012.

Buttner-Janz K, Schellnack K, Zippel H. Biomechanics of the SB Charite lumbar intervertebral disc endoprosthesis. Int Orthop 1989;13:173-6.

Buttner-Janz K. Optimal minimally traumatic approach for the SB Charite artificial disc. Eur Spine $J$ 2002;11 Suppl 2:S111-4.

Cabraja M, Schmeding M, Koch A, et al. Delayed formation of a devastating granulomatous process after metal-to-metal lumbar disc arthroplasty. Spine 2012;37:E809-E13.

Cakir B, Schmidt R, Mattes T, et al. Index level mobility after total lumbar disc replacement: Is it beneficial or detrimental? Spine 2009;34:917-23.

Canadian Agency for Drugs and Technologies in Health. Compressible non-articulating disc prostheses: A review of clinical and cost-effectiveness, safety and guidelines. 2014.

Chen SH, Zhong ZC, Chen CS, et al. Biomechanical comparison between lumbar disc arthroplasty and fusion. Med Eng Phys 2009;31:244-53.

Chen WC, Liu YL, Lin KJ, et al. Concave polyethylene component improves biomechanical performance in lumbar total disc replacement--modified compressive-shearing test by finite element analysis. Med Eng Phys 2012;34:498-505. 
Chen WM, Park C, Lee K, et al. In situ contact analysis of the prosthesis components of ProDisc-L in lumbar spine following total disc replacement. Spine 2009;34:E716-23.

Choma TJ, Miranda J, Siskey R, et al. Retrieval analysis of a ProDisc-L total disc replacement. $J$ Spinal Disord Tech 2009;22:290-6.

Chung SK, Kim YE, Wang KC. Biomechanical effect of constraint in lumbar total disc replacement: A study with finite element analysis. Spine 2009;34:1281-6.

Chung SS, Lee CS, Kang CS, et al. The effect of lumbar total disc replacement on the spinopelvic alignment and range of motion of the lumbar spine. $J$ Spinal Disord Tech 2006;19:307-11.

Chung SS, Lee CS, Kang CS. Lumbar total disc replacement using ProDisc II: A prospective study with a 2-year minimum follow-up. J Spinal Disord Tech 2006;19:411-5.

Cinotti G, David T, Postacchini F. Results of disc prosthesis after a minimum follow-up period of 2 years. Spine 1996;21:995-1000.

Crawford NR. Biomechanics of lumbar arthroplasty. Neurosurg Clin N Am 2005;16:595-602.

Cunningham BW, Dmitriev AE, Hu N, et al. General principles of total disc replacement arthroplasty: Seventeen cases in a nonhuman primate model. Spine 2003;28:S118-24.

Cunningham BW, Gordon JD, Dmitriev AE, et al. Biomechanical evaluation of total disc replacement arthroplasty: An in vitro human cadaveric model. Spine 2003;28:S110-7.

Cunningham BW, Hu N, Zorn CM, et al. Bioactive titanium calcium phosphate coating for disc arthroplasty: Analysis of 58 vertebral end plates after 6- to 12-month implantation. Spine J 2009;9:836-45.

Cunningham BW, McAfee PC, Geisler FH, et al. Distribution of in vivo and in vitro range of motion following 1-level arthroplasty with the CHARITE artificial disc compared with fusion. J Neurosurg Spine 2008;8:7-12.

Cunningham BW. Basic scientific considerations in total disc arthroplasty. Spine J 2004;4:219S-30S.

Daftari TK, Chinthakunta SR, Ingalhalikar A, et al. Kinematics of a selectively constrained radiolucent anterior lumbar disc: Comparisons to hybrid and circumferential fusion. Clin Biomech (Bristol, Avon) 2012;27:759-65.

Daniels AH, Paller DJ, Koruprolu S, et al. Dynamic biomechanical examination of the lumbar spine with implanted total disc replacement using a pendulum testing system. Spine 2012;37:E1438-43.

David T. Long-term results of one-level lumbar arthroplasty: Minimum 10-year follow-up of the CHARITE artificial disc in 106 patients. Spine 2007;32:661-6.

David T. Lumbar disc prosthesis. Surgical technique, indications and clinical results in 22 patients with a minimum of 12 months follow-up. Eur Spine $J$ 1993;1:254-9.

David T. Revision of a Charite artificial disc 9.5 years in vivo to a new Charite artificial disc: Case report and explant analysis. Eur Spine J 2005;14:507-11.

de Maat GH, Punt IM, van Rhijn LW, et al. Removal of the Charite lumbar artificial disc prosthesis: Surgical technique. J Spinal Disord Tech 2009;22:334-9.

Delamarter R, Zigler JE, Balderston RA, et al. Prospective, randomized, multicenter Food and Drug Administration Investigational Device Exemption study of the ProDisc-L total disc replacement compared with circumferential arthrodesis for the treatment of two-level lumbar degenerative disc disease: Results at twenty-four months. J Bone Joint Surg Am 2011;93:1-11.

Delécrin J, Allain J, Beaurain J, et al. Does core mobility of lumbar total disc arthroplasty influence sagittal and frontal intervertebral displacement? Ra- 
diologic comparison with fixed-core prosthesis. $S A S$ J 2009;3:91-9.

Delecrin J, Allain J, Beaurain J, et al. Effects of lumbar artificial disc design on intervertebral mobility: In vivo comparison between mobile-core and fixedcore. Eur Spine J 2012;21:630-40.

Demetropoulos CK, Sengupta DK, Knaub MA, et al. Biomechanical evaluation of the kinematics of the cadaver lumbar spine following disc replacement with the ProDisc-L prosthesis. Spine 2010;35:26-31.

Denoziere G, Ku DN. Biomechanical comparison between fusion of two vertebrae and implantation of an artificial intervertebral disc. J Biomech 2006;39:766-75.

Devin CJ, Myers TG, Kang JD. Chronic failure of a lumbar total disc replacement with osteolysis. Report of a case with nineteen-year follow-up. J Bone Joint Surg Am 2008;90:2230-4.

Di Silvestre M, Bakaloudis G, Lolli F, et al. Two-level total lumbar disc replacement. Eur Spine J 2009;18 Suppl 1:64-70.

Dmitriev AE, Gill NW, Kuklo TR, et al. Effect of multilevel lumbar disc arthroplasty on the operativeand adjacent-level kinematics and intradiscal pressures: An in vitro human cadaveric assessment. Spine J 2008;8:918-25.

Dooris AP, Goel VK, Grosland NM, et al. Loadsharing between anterior and posterior elements in a lumbar motion segment implanted with an artificial disc. Spine 2001;26:E122-9.

Eijkelkamp MF, Hayen J, Veldhuizen AG, et al. Improving the fixation of an artificial intervertebral disc. Int $J$ Artif Organs 2002;25:327-33.

Eijkelkamp MF, van Donkelaar CC, Veldhuizen AG, et al. Requirements for an artificial intervertebral disc. Int J Artif Organs 2001;24:311-21.

Erkan S, Rivera Y, Wu C, et al. Biomechanical comparison of a two-level Maverick disc replacement with a hybrid one-level disc replacement and one-level anterior lumbar interbody fusion. Spine $J$ 2009;9:830-5.

Fantini GA, Pawar AY. Access related complications during anterior exposure of the lumbar spine. World J Orthop 2013;4:19-23.

Fayssoux R, Goldfarb NI, Vaccaro AR, et al. Indirect costs associated with surgery for low back pain-a secondary analysis of clinical trial data. Popul Health Manag 2010;13:9-13.

Flouzat-Lachaniette $\mathrm{CH}$, Guidon J, Allain J, et al. An uncommon case of mycoplasma hominis infection after total disc replacement. Eur Spine J 2013;22:394-8.

Francois J, Coessens R, Lauweryns P. Early removal of a Maverick disc prosthesis: Surgical findings and morphological changes. Acta Orthop Belg 2007;73:122-7.

Fritzell P, Berg S, Borgstrom F, et al. Cost effectiveness of disc prosthesis versus lumbar fusion in patients with chronic low back pain: Randomized controlled trial with 2-year follow-up. Eur Spine $J$ 2011;20:1001-11.

Gaffey JL, Ghanayem AJ, Voronov ML, et al. Effect of increasing implant height on lumbar spine kinematics and foraminal size using the ProDisc-L prosthesis. Spine 2010;35:1777-82.

Galbusera F, Bellini CM, Zweig T, et al. Design concepts in lumbar total disc arthroplasty. Eur Spine $J$ 2008;17:1635-50.

Gao SG, Lei GH, He HB, et al. Biomechanical comparison of lumbar total disc arthroplasty, discectomy, and fusion: Effect on adjacent-level disc pressure and facet joint force. J Neurosurg Spine 2011;15:507-14.

Garcia Vacas F, Ezquerro Juanco F, de la Blanca AP, et al. Flexion-extension response of a novel lumbar intervertebral disc prosthesis: A finite element study. Med Eng Phys 2014;73:273-81. 
Geisler F. Surgical treatment for discogenic low-back pain: Lumbar arthroplasty results in superior pain reduction and disability level improvement compared with lumbar fusion. $S A S J$ 2007;1:12-9.

Geisler FH, Blumenthal SL, Guyer RD, et al. Neurological complications of lumbar artificial disc replacement and comparison of clinical results with those related to lumbar arthrodesis in the literature: Results of a multicenter, prospective, randomized investigational device exemption study of Charite intervertebral disc. Invited submission from the joint section meeting on disorders of the spine and peripheral nerves, March 2004. J Neurosurg Spine 2004;1:143-54.

Geisler FH, Guyer RD, Blumenthal SL, et al. Effect of previous surgery on clinical outcome following 1-level lumbar arthroplasty. J Neurosurg Spine 2008;8:108-14.

Geisler FH, McAfee PC, Banco RJ, et al. Prospective, randomized, multicenter FDA IDE study of Charité artificial disc versus lumbar fusion: Effect at 5-year follow-up of prior surgery and prior discectomy on clinical outcomes following lumbar arthroplasty. $S A S$ J 2009;3:16-24.

German JW, Foley KT. Disc arthroplasty in the management of the painful lumbar motion segment.

Spine 2005;30:S60-7.

Gerometta A, Rodriguez Olaverri JC, Bittan F. Infection and revision strategies in total disc arthroplasty.

Int Orthop 2012;36:471-4.

Gioia G, Mandelli D, Randelli F. The Charite III artificial disc lumbar disc prosthesis:Assessment of medium term results. J Orthop Traumatol 2007;8:134-9.

Gloria A, Causa F, De Santis R, et al. Dynamic-mechanical properties of a novel composite intervertebral disc prosthesis. J Mater Sci Mater Med 2007;18:2159-65.

Goel VK, Grauer JN, Patel T, et al. Effects of Charite artificial disc on the implanted and adjacent spinal segments mechanics using a hybrid testing protocol. Spine 2005;30:2755-64.

Goreham-Voss CM, Vicars R, Hall RM, et al. Preferential superior surface motion in wear simulations of the Charite total disc replacement. Eur Spine J 2012;21:700-8.

Gornet M. Maverick total disc replacement. In Yue JJ, Bertagnoli R, McAfee PC eds. Motion preservation surgery of the spine: Advanced techniques and controversies. Philadelphia, PA: Saunders Elsivier, 2008:353-62.

Gornet MF, Burkus JK, Dryer RF, et al. Lumbar disc arthroplasty with Maverick disc versus stand-alone interbody fusion: A prospective, randomized, controlled, multicenter Investigational Device Exemption trial. Spine 2011;36:E1600-E11.

Gornet MF, Burkus JK, Harper ML, et al. Prospective study on serum metal levels in patients with metal-on-metal lumbar disc arthroplasty. Eur Spine J 2013;22:741-6.

Gornet MF, Dryer RF, Peloza JH, et al. Lumbar disc arthroplasty vs. Anterior lumbar interbody fusion: Five-year outcomes for patients in the Maverick disc IDE study. North American Spine Society. Orlando, FL, 2010.

Gornet MF, Schranck F, Wharton ND, et al. Optimizing success with lumbar disc arthroplasty. Eur Spine J 2014;23:2127-35.

Gottfried ON, Brodke DS. Traumatic burst fracture in a patient with a lumbar artificial disc. J Neurosurg Spine 2009;11:353-7.

Gragnaniello C, Seex KA, Eisermann LG, et al. Early postoperative dislocation of the anterior maverick lumbar disc prosthesis: Report of 2 cases. J Neurosurg Spine 2013;19:191-6.

Grupp TM, Yue JJ, Garcia R, Jr., et al. Biotribological evaluation of artificial disc arthroplasty devices: Influence of loading and kinematic patterns during in vitro wear simulation. Eur Spine J 2009;18:98-108. 
Grupp TM, Yue JJ, Garcia R, Jr., et al. Evaluation of impingement behaviour in lumbar spinal disc arthroplasty. Eur Spine J in press.

Gstoettner M, Heider D, Liebensteiner M, et al. Footprint mismatch in lumbar total disc arthroplasty. Eur Spine J 2008;18:118.

Guyer RD, Geisler FH, Blumenthal SL, et al. Effect of age on clinical and radiographic outcomes and adverse events following 1-level lumbar arthroplasty after a minimum 2-year follow-up. J Neurosurg Spine 2008;8:101-7.

Guyer RD, McAfee PC, Banco RJ, et al. Prospective, randomized, multicenter Food and Drug Administration Investigational Device Exemption study of lumbar total disc replacement with the CHARITE artificial disc versus lumbar fusion: Five-year follow-up. Spine J 2009;9:374-86.

Guyer RD, Pettine K, Dimmig TC, D., et al. Fiveyear follow-up of a prospective, randomized FDA IDE trial comparing two lumbar total disc replacements: Clinical outcome and serum ion level analysis for a metal-on-metal device. International Society for the Study of the Lumbar Spine. Scottsdale, AZ, 2013.

Guyer RD, Pettine K, Roh JS, et al. Comparison of 2 lumbar total disc replacements: Results of a prospective, randomized, controlled multicenter Food and Drug Administration trial with 24-month follow-up. Spine 2014;39:925-31.

Guyer RD, Shellock J, Maclennan B, et al. Early failure of metal-on-metal artificial disc prostheses associated with lymphocytic reaction: Diagnosis and treatment experience in 4 cases. Spine 2011;36:E492-E7.

Guyer RD, Siddiqui S, Zigler JE, et al. Lumbar spinal arthroplasty: Analysis of one center's twenty best and twenty worst clinical outcomes. Spine 2008;33:2566-9.

Guyer RD, Tromanhauser SG, Regan JJ. An economic model of one-level lumbar arthroplasty versus fusion. Spine J 2007;7:558-62.

Ha SK, Kim SH, Kim DH, et al. Biomechanical study of lumbar spinal arthroplasty with a semi-constrained artificial disc (Activ-L) in the human cadaveric spine. J Korean Neurosurg Soc 2009;45:169-75.

Hähnle UR, Sliwa K, Weinberg IR, et al. Lumbar disc replacement for junctional decompensation after fusion surgery: Clinical and radiological outcome at an average follow-up of 33 months $S A S J$ 2007;1:83-95.

Hahnle UR, Weinberg IR, Sliwa K, et al. Kineflex (Centurion) lumbar disc prosthesis: Insertion technique and 2-year clinical results in 100 patients. $S A S$ J 2007;1:28-35.

Hallab N, Link HD, McAfee PC. Biomaterial optimization in total disc arthroplasty. Spine 2003;28:S139-52.

Hannibal M, Thomas DJ, Low J, et al. ProDisc-l total disc replacement: A comparison of 1-level versus 2-level arthroplasty patients with a minimum 2-year follow-up. Spine 2007;32:2322-6.

Harris IA, Dantanarayana N, Naylor JM. Spine surgery outcomes in a workers' compensation cohort. ANZ J Surg 2012;82:625-9.

Harrison WD, Harrison DJ. The use of percutaneous lumbar fixation screws for bilateral pedicle fractures with an associated dislocation of a lumbar disc prosthesis. Case Rep Orthop 2013;2013:676017.

Harrop JS, Youssef JA, Maltenfort M, et al. Lumbar adjacent segment degeneration and disease after arthrodesis and total disc arthroplasty. Spine 2008;33:1701-7.

Hedman TP, Kostuik JP, Fernie GR, et al. Design of an intervertebral disc prosthesis. Spine 1991;16:S256-60.

Hellum C, Berg L, Gjertsen O, et al. Adjacent level degeneration and facet arthropathy after disc prosthesis surgery or rehabilitation in patients with 
chronic low back pain and degenerative disc: Second report of a randomized study. Spine 2012;37:2063-73.

Hellum C, Johnsen LG, Storheim K, et al. Surgery with disc prosthesis versus rehabilitation in patients with low back pain and degenerative disc: Two year follow-up of randomised study. $B M J$ 2011;342:d2786.

Herkowitz HN. Total disc replacement with the CHARITE artificial disc was as effective as lumbar interbody fusion. J Bone Joint Surg Am 2006;88:1168.

Hitchon PW, Eichholz K, Barry C, et al. Biomechanical studies of an artificial disc implant in the human cadaveric spine. J Neurosurg Spine 2005;2:339-43.

Holt RT, Majd ME, Isaza JE, et al. Complications of lumbar artificial disc replacement compared to fusion: Results from the prospective, randomized, multicenter us Food and Drug Administration Investigational Device Exemption study of the Charite artificial disc. $S A S$ J 2007;1:20-7.

Hou TS, Tu KY, Xu YK, et al. Lumbar intervertebral disc prosthesis. An experimental study. Chin Med J (Engl) 1991;104:381-6.

Huang RC, Girardi FP, Cammisa FP, Jr., et al. Correlation between range of motion and outcome after lumbar total disc replacement: 8.6-year follow-up. Spine 2005;30:1407-11.

Huang RC, Girardi FP, Cammisa FP, Jr., et al. The implications of constraint in lumbar total disc replacement. J Spinal Disord Tech 2003;16:412-7.

Huang RC, Girardi FP, Cammisa Jr FP, et al. Longterm flexion-extension range of motion of the prodisc total disc replacement. J Spinal Disord Tech 2003;16:435-40.

Huang RC, Tropiano P, Marnay T, et al. Range of motion and adjacent level degeneration after lumbar total disc replacement. Spine J 2006;6:242-7.

Hyde PJ, Tipper J, Fisher J, et al. Wear and biological effects of a semi-constrained total disc replacement subject to modified iso standard test conditions. $J$ Mech Behav Biomed Mater 2014;44C:43-52.

Ingalhalikar AV, Reddy CG, Lim TH, et al. Effect of lumbar total disc arthroplasty on the segmental motion and intradiscal pressure at the adjacent level: An in vitro biomechanical study: Presented at the 2008 joint spine section meeting laboratory investigation. J Neurosurg Spine 2009;11:715-23.

Jacobs W, Van der Gaag NA, Tuschel A, et al. Total disc replacement for chronic back pain in the presence of disc degeneration. Cochrane Database Syst Rev 2012;9:CD008326.

Jacobs WC, Van der Gaag NA, Kruyt MC, et al. Total disc replacement for chronic discogenic low-back pain: A cochrane review. Spine 2013;38:24-36.

Jehan S, Elsayed S, Webb J, et al. L5-S1 disc replacement after two previous fusion surgeries for scoliosis. Eur Spine J 2011;20:669-73.

Jeon SH, Choi WG, Lee SH. Anterior revision of a dislocated ProDisc prosthesis at the 14-5 level. $J$ Spinal Disord Tech 2008;21:448-50.

Johnsen LG, Brinckmann P, Hellum C, et al. Segmental mobility, disc height and patient-reported outcomes after surgery for degenerative disc disease: A prospective randomised trial comparing disc replacement and multidisciplinary rehabilitation. Bone Joint J 2013;95-B:81-9.

Johnsen LG, Hellum C, Storheim K, et al. Cost-effectiveness of total disc replacement versus multidisciplinary rehabilitation in patients with chronic low back pain: A Norwegian multicenter rct. Spine 2014;39:23-32.

Jones CW, Smitham P, Walsh WR. Relationship of surgical accuracy and clinical outcomes in charite lumbar disc replacement. Orthop Surg 2012;4:145-55.

Kafchitsas K, Kokkinakis M, Habermann B, et al. Effect of lumbar disc replacement on the height of the disc space and the geometry of the facet joints: A ca- 
daver study. J Bone Joint Surg Br 2010;92:595-601.

Kafer W, Clessienne CB, Daxle M, et al. Posterior component impingement after lumbar total disc replacement: A radiographic analysis of 66 ProDisc-L prostheses in 56 patients. Spine 2008;33:2444-9.

Kasliwal MK, Deutsch H. Effect of total lumbar disc replacement on lumbosacral lordosis. J Spinal Disord Tech 2012;25:370-3.

Katsimihas M, Bailey CS, Issa K, et al. Prospective clinical and radiographic results of CHARITE III artificial total disc arthroplasty at 2- to 7-year followup: A Canadian experience. Can J Surg 2010;53:408-4145.

Kerr EJ, Jawahar A, Kay S, et al. Implant design may influence delayed heterotopic ossification after total disk arthroplasty in lumbar spine. Surg Neurol 2009;72:747-51

Kikkawa J, Cunningham BW, Shirado O, et al. Biomechanical evaluation of a posterolateral lumbar disc arthroplasty device: An in vitro human cadaveric model. Spine 2010;35:1760-8.

Kim DH, Ryu KS, Kim MK, et al. Factors influencing segmental range of motion after lumbar total disc replacement using the ProDisc II prosthesis. $J \mathrm{Neu}$ rosurg Spine 2007;7:131-8.

Kim KT, Lee SH, Suk KS, et al. Biomechanical changes of the lumbar segment after total disc replacement : Charite(r), ProDisc(r) and Maverick(r) using finite element model study. J Korean Neurosurg Soc 2010;47:446-53.

Knapik GG, Mendel E, Marras WS. Use of a personalized hybrid biomechanical model to assess change in lumbar spine function with a TDR compared to an intact spine. Eur Spine J 2012;21 Suppl 5:S641-52.

Kotani Y, Abumi K, Shikinami Y, et al. Artificial intervertebral disc replacement using bioactive threedimensional fabric: Design, development, and preliminary animal study. Spine 2002;27:929-35
Kotani Y, Abumi K, Shikinami Y, et al. Two-year observation of artificial intervertebral disc replacement: Results after supplemental ultra-high strength bioresorbable spinal stabilization. J Neurosurg 2004;100:337-42.

Kotani Y, Cunningham BW, Abumi K, et al. Multidirectional flexibility analysis of anterior and posterior lumbar artificial disc reconstruction: In vitro human cadaveric spine model. Eur Spine J 2006;15:1511-20.

Kurtz SM, Lau E, Ianuzzi A, et al. National revision burden for lumbar total disc replacement in the United States: Epidemiologic and economic perspectives. Spine 2010;35:690-6.

Kurtz SM, Patwardhan A, MacDonald D, et al. What is the correlation of in vivo wear and damage patterns with in vitro TDR motion response? Spine 2008;33:481-9.

Kurtz SM, Peloza J, Siskey R, et al. Analysis of a retrieved polyethylene total disc replacement component. Spine J 2005;5:344-50.

Kurtz SM, Toth JM, Siskey R, et al. The latest lessons learned from retrieval analyses of ultra-high molecular weight polyethylene, metal-on-metal, and alternative bearing total disc replacements. Semin Spine Surg 2012;24:57-70.

Lakshmanan P, Purushothaman B, Dvorak V, et al. Sagittal endplate morphology of the lower lumbar spine. Eur Spine J 2012;21 Suppl 2:S160-4.

Langrana NA, Lee CK, Yang SW. Finite-element modeling of the synthetic intervertebral disc. Spine 1991;16:S245-52.

Langrana NA, Parsons JR, Lee CK, et al. Materials and design concepts for an intervertebral disc spacer. I. Fiber-reinforced composite design. J Appl Biomater 1994;5:125-32.

Laouissat F, Allain J, Delecrin J. Intraoperative determination of lumbar prosthesis endplate lordotic angulation to improve motion. Orthop Traumatol Surg Res in press. 
Lazennec JY, Aaron A, Brusson A, et al. The LP$\operatorname{ESP}((\mathrm{r}))$ lumbar disc prosthesis with 6 degrees of freedom: Development and 7 years of clinical experience. Eur J Orthop Surg Traumatol 2013;23:131-43.

Lazennec JY, Even J, Skalli W, et al. Clinical outcomes, radiologic kinematics, and effects on sagittal balance of the $6 \mathrm{df}$ LP-ESP lumbar disc prosthesis. Spine J 2014;14:1914-20.

Le Huec J, Basso Y, Mathews H, et al. The effect of single-level, total disc arthroplasty on sagittal balance parameters: A prospective study. Eur Spine J 2005;14:480-6.

Le Huec JC, Basso Y, Aunoble S, et al. Influence of facet and posterior muscle degeneration on clinical results of lumbar total disc replacement: Two-year follow-up. J Spinal Disord Tech 2005;18:219-23.

Le Huec JC, Kiaer T, Friesem T, et al. Shock absorption in lumbar disc prosthesis: A preliminary mechanical study. J Spinal Disord Tech 2003;16:346-51.

Le Huec JC, Mathews H, Basso Y, et al. Clinical results of maverick lumbar total disc replacement: Two-year prospective follow-up. Orthop Clin North Am 2005;36:315-22.

Leahy M, Zigler JE, Ohnmeiss DD, et al. Comparison of results of total disc replacement in postdiscectomy patients versus patients with no previous lumbar surgery. Spine 2008;33:1690-3.

Leary SP, Regan JJ, Lanman TH, et al. Revision and explantation strategies involving the CHARITE lumbar artificial disc replacement. Spine 2007;32:1001-11.

Lebl DR, Cammisa FP, Girardi FP, et al. In vivo functional performance of failed proDisc-L devices: Retrieval analysis of lumbar total disc replacements. Spine 2012;37:E1209-17.

Lee CK, Langrana NA, Parsons JR, et al. Development of a prosthetic intervertebral disc. Spine 1991;16:S253-5.
Lee CK. Osteopenia and total disc prosthesis subsidence: Inclusion/exclusion criteria for total disc replacement. $S A S$ J 2007;1:82-4.

Lee CS, Chung SS, Oh SK, et al. Significance of angular mismatch between vertebral endplate and prosthetic endplate in lumbar total disc replacement. $J$ Spinal Disord Tech 2011;24:183-8.

Lee CS, Lee DH, Hwang CJ, et al. The effect of a mismatched center of rotation on the clinical outcomes and flexion-extension range of motion: Lumbar total disk replacement using Mobidisc at a 5.5-year follow-up. J Spinal Disord Tech 2014;27:148-53.

Lee JL, Billi F, Sangiorgio SN, et al. Wear of an experimental metal-on-metal artificial disc for the lumbar spine. Spine 2008;33:597-606.

Leivseth G, Braaten S, Frobin W, et al. Mobility of lumbar segments instrumented with a ProDisc II prosthesis: A two-year follow-up study. Spine 2006;31:1726-33.

Lemaire JP, Carrier H, Sariali el H, et al. Clinical and radiological outcomes with the Charite artificial disc: A 10-year minimum follow-up. J Spinal Disord Tech 2005;18:353-9.

Lemaire JP, Skalli W, Lavaste F, et al. Intervertebral disc prosthesis. Results and prospects for the year 2000. Clin Orthop Relat Res 1997:64-76.

Levin DA, Bendo JA, Quirno M, et al. Comparative charge analysis of one- and two-level lumbar total disc arthroplasty versus circumferential lumbar fusion. Spine 2007;32:2905-9.

Li Y, Hresko MT. Lumbar spine surgery in athletes: Outcomes and return-to-play criteria. Clin Sports Med 2012;31:487-98.

Li ZY, Han X, Ma S, et al. Effect of total lumbar disc replacement on the treatment of discogenic low lumbar pain: Preliminary outcomes. Chin Med J (Engl) 2013;126:1504-8. 
Link HD. History, design and biomechanics of the link SB Charite artificial disc. Eur Spine J 2002;11 Suppl 2:S98-S105.

Lu S, Kong C, Hai Y, et al. Prospective clinical and radiographic results of active 1 total disc replacement at 1- to 4-year follow-up. J Spinal Disord Tech in press.

Lu S, Kong C, Hai Y, et al. Retrospective study on effectiveness of activ 1 total disc replacement: Clinical and radiographic results of 1- to 3-year follow-up. Spine in press.

Magaji SA, Debnath UK, Mehdian HS. Compartment syndrome of leg following total lumbar disc replacement via anterior retroperitoneal approach: A rare complication of anterior spinal surgery. Spine 2010;35:E74-6.

Magnussen LH. Surgery with disc prosthesis may produce better outcomes than multidisciplinary rehabilitation for patients with chronic low back pain. $J$ Physiother 2011;57:257.

Mahomed A, Moghadas PM, Shepherd DE, et al. Effect of axial load on the flexural properties of an elastomeric total disc replacement. Spine 2012;37:E908-E12.

Markwalder TM, Wenger M, Marbacher S. A 6.5-year follow-up of 14 patients who underwent ProDisc total disc arthroplasty for combined longstanding degenerative lumbar disc disease and recent disc herniation. J Clin Neurosci 2011;18:1677-81.

Marshman LA, Friesem T, Rampersaud YR, et al. Subsidence and malplacement with the oblique maverick lumbar disc arthroplasty: Technical note. Spine $J$ 2008;8:650-5.

Marshman LA, Trewhella M, Friesem T, et al. The accuracy and validity of "Routine" X-rays in estimating lumbar disc arthroplasty placement. Spine 2007;32:E661-E6.

Mathew P, Blackman M, Redla S, et al. Bilateral pedicle fractures following anterior dislocation of the polyethylene inlay of a ProDisc artificial disc replacement: A case report of an unusual complication.

Spine 2005;30:E311-4.

Mathews HH, Lehuec JC, Friesem T, et al. Design rationale and biomechanics of Maverick total disc arthroplasty with early clinical results. Spine J 2004;4:268S-75S.

McAfee PC, Cunningham B, Holsapple G, et al. A prospective, randomized, multicenter Food and Drug Administration investigational device exemption study of lumbar total disc replacement with the CHARITE artificial disc versus lumbar fusion: Part II: Evaluation of radiographic outcomes and correlation of surgical technique accuracy with clinical outcomes. Spine 2005;30:1576-83.

McAfee PC, Cunningham BW, Hayes V, et al. Biomechanical analysis of rotational motions after disc arthroplasty: Implications for patients with adult deformities. Spine 2006;31:S152-60.

McAfee PC, Cunningham BW, Orbegoso CM, et al. Analysis of porous ingrowth in intervertebral disc prostheses: A nonhuman primate model. Spine 2003;28:332-40.

McAfee PC, Geisler FH, Saiedy SS, et al. Revisability of the CHARITE artificial disc replacement: Analysis of 688 patients enrolled in the U.S. IDE study of the CHARITE artificial disc. Spine 2006;31:1217-26.

McAfee PC, Salari B, Saiedy S. Reoperations and complications of failed lumbar total disk replacement Semin Spine Surg 2012;24::37-42

McCormick PC. Lumbar disc arthroplasty compared with interbody fusion. J Neurosurg Spine 2008;8:3-5.

Meir AR, Freeman BJ, Fraser RD, et al. Ten-year survival and clinical outcome of the Acroflex lumbar disc replacement for the treatment of symptomatic disc degeneration. Spine J 2013;13:13-21.

Michaela G, Denise H, Liebensteiner M, et al. Footprint mismatch in lumbar total disc arthroplasty. Eur 
Spine J 2008;17:1470-5.

Moghadas PM, Shepherd DE, Hukins DW, et al. Polymer-on-metal or metal-on-polymer total disc arthroplasty: Does it make a difference? Spine 2012;37:1834-8.

Mohapatra B, Kishen T, Loi KWK, et al. Retroperitoneal lymphocele after lumbar total disc replacement: A case report and review of literature. $S A S J$ 2010;4:87-91.

Murtagh RD, Quencer RM, Cohen DS, et al. Normal and abnormal imaging findings in lumbar total disk replacement: Devices and complications. Radiographics 2009;29:105-18.

Nie H, Chen G, Wang X, et al. Comparison of total disc replacement with lumbar fusion: A meta-analysis of randomized controlled trials. J Coll Physicians Surg Pak 2015;25:60-7.

Noailly J, Ambrosio L, Elizabeth Tanner K, et al. In silico evaluation of a new composite disc substitute with a L3-L5 lumbar spine finite element model. Eur Spine J 2012;21:675-87.

Noailly J, Lacroix D, Planell JA. Finite element study of a novel intervertebral disc substitute. Spine 2005;30:2257-64.

Oetgen ME, Yue JJ, Jaramillo-de la Torre JJ, et al. Does vertebral endplate morphology influence outcomes in lumbar total disc arthroplasty? Part II: Clinical and radiographic results as evaluated utilizing the vertebral endplate Yue-Bertagnoli (veybr) classification. $S A S$ J 2008;2:101-6.

Ohnmeiss DD, Bodemer W, Zigler JE. Effect of adverse events on low back surgery outcome: Twentyfour-month follow-up results from a food and drug administration investigational device exemption trial. Spine 2010;35:835-8.

Oktenoglu T, Ozer AF, Sasani M, et al. Posterior transpedicular dynamic stabilization versus total disc replacement in the treatment of lumbar painful degenerative disc disease: A comparison of clinical re- sults. Adv Orthop 2013;2013:874090.

O'Leary P, Nicolakis M, Lorenz MA, et al. Response of Charite total disc replacement under physiologic loads: Prosthesis component motion patterns. Spine J 2005;5:590-9.

Ordway NR, Amir H. Fayyazi AH, Abjornson C, et al. Twelve-month follow-up of lumbar spine range of motion following intervertebral disc replacement using radiostereometric analysis. $S A S J$ 2008;2:9-15.

Panjabi M, Henderson G, Abjornson C, et al. Multidirectional testing of one- and two-level ProDisc-L versus simulated fusions. Spine 2007;32:1311-9.

Panjabi M, Malcolmson G, Teng E, et al. Hybrid testing of lumbar CHARITE discs versus fusions. Spine 2007;32:959-66.

Park CK, Ryu KS, Jee WH. Degenerative changes of discs and facet joints in lumbar total disc replacement using ProDisc II: Minimum two-year follow-up. Spine 2008;33:1755-61.

Park CK, Ryu KS, Lee KY, et al. Clinical outcome of lumbar total disc replacement using ProDisc-L(r) in degenerative disc disease: Minimum 5-year follow-up results at a single institute. Spine 2012;37:672-7.

Park SJ, Kang KJ, Shin SK, et al. Heterotopic ossification following lumbar total disc replacement. Int Orthop 2011;35:1197-201.

Parkinson B, Goodall S, Thavaneswaran P. Cost-effectiveness of lumbar artificial intervertebral disc replacement: Driven by the choice of comparator. $A N Z$ J Surg 2013;83:669-75.

Patel AA, Brodke DS, Pimenta L, et al. Revision strategies in lumbar total disc arthroplasty. Spine 2008;33:1276-83.

Patel VV, Estes S, Lindley EM, et al. Lumbar spinal fusion versus anterior lumbar disc replacement: The financial implications. J Spinal Disord Tech 2008;21:473-6. 
Peng CW, Bendo JA, Goldstein JA, et al. Perioperative outcomes of anterior lumbar surgery in obese versus non-obese patients. Spine J 2008;8:86S-7S.

Petilon J, Roth J, Hardenbrook M. Results of lumbar total disc arthroplasty in military personnel. J Spinal Disord Tech 2011;24:297-301.

Pimenta L, Diaz RC, Guerrero LG. Charite lumbar artificial disc retrieval: Use of a lateral minimally invasive technique. Technical note. J Neurosurg Spine 2006;5:556-61.

Pimenta L, Oliveira L, Schaffa T, et al. Lumbar total disc replacement from an extreme lateral approach: Clinical experience with a minimum of 2 years' follow-up. J Neurosurg Spine 2011;14:38-45.

Pimenta L, Springmuller R, Lee CK, et al. Clinical performance of an elastomeric lumbar disc replacement: Minimum 12 months follow-up. $S A S J$ 2010;4:16-25.

Pimenta L, Turner A, Oliveira L, et al. Controlled motion with the XL-TDR lateral-approach lumbar total disk replacement: In vitro kinematic investigation. J Neurol Surg A Cent Eur Neurosurg, in press.

Pimenta L, Turner A, Oliveira L, et al. Controlled motion with the XL-TDR lateral-approach lumbar total disk replacement: In vitro kinematic investigation. J Neurol Surg A Cent Eur Neurosurg 2015;76:133-8.

Punt I, Baxter R, van Ooij A, et al. Submicron sized ultra-high molecular weight polyethylene wear particle analysis from revised SB Charite III total disc replacements. Acta Biomater 2011;7:3404-11.

Punt I, van Rijsbergen M, van Rietbergen B, et al. Subsidence of SB Charite total disc replacement and the role of undersizing. Eur Spine J 2013;22:2264-70.

Punt I, Willems P, Kurtz S, et al. Clinical outcomes of two revision strategies for failed total disc replacements. Eur Spine J 2012;21:2558-64.

Punt IM, Austen S, Cleutjens JP, et al. Are peripros- thetic tissue reactions observed after revision of total disc replacement comparable to the reactions observed after total hip or knee revision surgery? Spine 2012;37:150-9.

Punt IM, Cleutjens JP, de Bruin T, et al. Periprosthetic tissue reactions observed at revision of total intervertebral disc arthroplasty. Biomaterials 2009;30:2079-84.

Punt IM, Visser VM, van Rhijn LW, et al. Complications and reoperations of the SB Charite lumbar disc prosthesis: Experience in 75 patients. Eur Spine $J$ 2008;17:36-43.

Putzier M, Funk JF, Schneider SV, et al. Charite total disc replacement--clinical and radiographical results after an average follow-up of 17 years. Eur Spine $J$ 2006;15:183-95.

Quirno M, Kamerlink JR, Valdevit A, et al. Biomechanical analysis of a disc prosthesis distal to a scoliosis model. Spine 2009;34:1470-5.

Rainey S, Blumenthal SL, Zigler JE, et al. Analysis of adjacent segment re-operation following lumbar total disc replacement. Internat J Spine Surg 2012;6:140-4.

Rao MJ, Cao SS. Artificial total disc replacement versus fusion for lumbar degenerative disc disease: A meta-analysis of randomized controlled trials. Arch Orthop Trauma Surg 2014;134:149-58.

Rawlinson JJ, Punga KP, Gunsallus KL, et al. Wear simulation of the ProDisc-L disc replacement using adaptive finite element analysis. J Neurosurg Spine 2007;7:165-73.

Regan JJ, McAfee PC, Blumenthal SL, et al. Evaluation of surgical volume and the early experience with lumbar total disc replacement as part of the investigational device exemption study of the Charite artificial disc. Spine 2006;31:2270-6.

Rischke B, Ross RS, Jollenbeck BA, et al. Preclinical and clinical experience with a viscoelastic total disc replacement. $S A S$ J 2011;5:97-107. 
Rohan MX, Jr., Ohnmeiss DD, Guyer RD, et al. Relationship between the length of time off work preoperatively and clinical outcome at 24-month follow-up in patients undergoing total disc replacement or fusion. Spine J 2009;9:360-5.

Rohlmann A, Lauterborn S, Dreischarf M, et al. Parameters influencing the outcome after total disc replacement at the lumbosacral junction. Part 1: Misalignment of the vertebrae adjacent to a total disc replacement affects the facet joint and facet capsule forces in a probabilistic finite element analysis. Eur Spine J 2013;22:2271-8.

Rohlmann A, Mann A, Zander T, et al. Effect of an artificial disc on lumbar spine biomechanics: A probabilistic finite element study. Eur Spine $J$ 2009;18:89-97.

Rohlmann A, Zander T, Bock B, et al. Effect of position and height of a mobile core type artificial disc on the biomechanical behaviour of the lumbar spine.

Proc Inst Mech Eng H 2008;222:229-39.

Rosen C, Kiester D, Lee TQ. The potential biomechanical etiology for lumbar disc replacement failures: Review of 24 patients and the rationale for revision. Internet J Minimally Invasive Spinal Tech 2007;1.

Rosen C, Kiester PD, Lee TQ. Lumbar disk replacement failures: Review of 29 patients and rationale for revision. Orthopedics 2009;32.

Ross R, Mirza AH, Norris HE, et al. Survival and clinical outcome of SB Charite III disc replacement for back pain. J Bone Joint Surg Br 2007;89:785-9.

Rousseau MA, Bradford DS, Bertagnoli R, et al. Disc arthroplasty design influences intervertebral kinematics and facet forces. Spine $J$ 2006;6:258-66.

Rundell SA, Auerbach JD, Balderston RA, et al. Total disc replacement positioning affects facet contact forces and vertebral body strains. Spine 2008;33:2510-7.

Rundell SA, Day JS, Isaza J, et al. Lumbar total disc replacement impingement sensitivity to disc height distraction, spinal sagittal orientation, implant position, and implant lordosis. Spine 2012;37:E590-E8.

Saavedra-Pozo FM, Deusdara RA, Benzel EC. Adjacent segment disease perspective and review of the literature. Ochsner J 2014;14:78-83.

SariAli E-H, Lemaire JP, Pascal-Mousselard H, et al. In vivo study of the kinematics in axial rotation of the lumbar spine after total intervertebral disc replacement: Long-term results: A 10-14 years follow up evaluation. Eur Spine J 2006;15:1501-10.

Sasani M, Oktenoglu T, Tuncay K, et al. Total disc replacement in the treatment of lumbar discogenic pain with disc herniation: A prospective clinical study. Turk Neurosurg 2009;19:127-34.

Sasso RC, Foulk DM, Hahn M. Prospective, randomized trial of metal-on-metal artificial lumbar disc replacement: Initial results for treatment of discogenic pain. Spine 2008;33:123-31.

Schluessmann E, Diel P, Aghayev E, et al.

SwissSpine: A nationwide registry for health technology assessment of lumbar disc prostheses. Eur Spine J 2009;18:851-61.

Schmidt H, Galbusera F, Rohlmann A, et al. Effect of multilevel lumbar disc arthroplasty on spine kinematics and facet joint loads in flexion and extension: A finite element analysis. Eur Spine $J$ 2012;21:663-74.

Schmidt H, Midderhoff S, Adkins K, et al. The effect of different design concepts in lumbar total disc arthroplasty on the range of motion, facet joint forces and instantaneous center of rotation of a 14-5 segment. Eur Spine J 2009;18:1695-705.

Schmiedberg SK, Chang DH, Frondoza CG, et al. Isolation and characterization of metallic wear debris from a dynamic intervertebral disc prosthesis. J Biomed Mater Res 1994;28:1277-88.

Schroven I, Dorofey D. Intervertebral prosthesis versus anterior lumbar interbody fusion: One-year re- 
sults of a prospective non-randomised study. Acta Orthop Belg 2006;72:83-6.

Schulte TL, Lerner T, Hackenberg L, et al. Acquired spondylolysis after implantation of a lumbar ProDisc II prosthesis: Case report and review of the literature. Spine 2007;32:E645-8.

Schwarzenbach O. Hybrid stabilization with ALIF L5/S1 and total disc replacement L4/L5. Eur Spine J 2009;18:1995-6.

Scott-Young MN, Lee MJ, Nielsen DE, et al. Clinical and radiological mid-term outcomes of lumbar single-level total disc replacement. Spine in press.

Sekhon LH. Postoperative imaging of spinal disk arthroplasty devices. Semin Spine Surg

2012;24:48-56

Serhan HA, Dooris AP, Parsons ML, et al. In vitro wear assessment of the Charite artificial disc according to ASTM recommendations. Spine 2006;31:1900-10.

Serhan HA, Dooris AP, Parsons ML, et al. In vitro wear assessment of the Charite artificial disc according to astm recommendations. Spine

2006;31:1900-10.

Shaheen A, Shepherd DE. Lubrication regimes in lumbar total disc arthroplasty. Proc Inst Mech Eng [H] 2007;221:621-7.

Shedid D, Ugokwe KT, Benzel EC. Lumbar total disc replacement compared with spinal fusion: Treatment choice and evaluation of outcome. Nat Clin Pract Neurol 2005;1:4-5.

Sheibani-Rad S. Pedicle stress fracture following total disc replacement: Case report of a rare complication, and literature review. Univ Penn Orthop $J$ in press; 19 .

Shikinami Y, Kawabe Y, Yasukawa K, et al. A biomimetic artificial intervertebral disc system composed of a cubic three-dimensional fabric. Spine $J$ 2010;10:141-52.
Shim CS, Lee S, Maeng DH, et al. Vertical split fracture of the vertebral body following total disc replacement using ProDisc: Report of two cases. $J$ Spinal Disord Tech 2005;18:465-9.

Shim CS, Lee SH, Shin HD, et al. CHARITE versus ProDisc: A comparative study of a minimum 3-year follow-up. Spine 2007;32:1012-8.

Shimamura Y, Holding C, Haynes DR, et al. The biologic response to particles from a potential disc prosthesis material. Spine 2008;33:351-5.

Shin MH, Ryu KS, Hur JW, et al. Association of facet tropism and progressive facet arthrosis after lumbar total disc replacement using ProDisc-L. Eur Spine J 2013;22:1717-22.

Siepe CJ, Heider F, Haas E, et al. Influence of lumbar intervertebral disc degeneration on the outcome of total lumbar disc replacement: A prospective clinical, histological, x-ray and MRI investigation. Eur Spine J 2012;21:2287-99.

Siepe CJ, Heider F, Wiechert K, et al. Mid- to longterm results of total lumbar disc replacement: A prospective analysis with 5- to 10-year follow-up. Spine J 2014;14:1417-31.

Siepe CJ, Hitzl W, Meschede P, et al. Interdependence between disc space height, range of motion and clinical outcome in total lumbar disc replacement. Spine 2009;34:904-16.

Siepe CJ, Korge A, Grochulla F, et al. Analysis of post-operative pain patterns following total lumbar disc replacement: Results from fluoroscopically guided spine infiltrations. Eur Spine J 2008;17:44-56.

Siepe CJ, Mayer HM, Heinz-Leisenheimer M, et al. Total lumbar disc replacement: Different results for different levels. Spine 2007;32:782-90.

Siepe CJ, Mayer HM, Wiechert K, et al. Clinical results of total lumbar disc replacement with ProDisc II: Three-year results for different indications. Spine 2006;31:1923-32. 
Siepe CJ, Wiechert K, Khattab MF, et al. Total lumbar disc replacement in athletes: Clinical results, return to sport and athletic performance. Eur Spine J 2007;16:1001-13.

Siepe CJ, Zelenkov P, Sauri-Barraza JC, et al. The fate of facet joint and adjacent level disc degeneration following total lumbar disc replacement: A prospective clinical, $\mathrm{x}$-ray, and magnetic resonance imaging investigation. Spine 2010;35:1991-2003.

Sinigaglia R, Bundy A, Costantini S, et al. Comparison of single-level 14-15 versus 15-s1 lumbar disc replacement: Results and prognostic factors. Eur Spine J 2009; 18:52-63.

Skold C, Tropp H, Berg S. Five-year follow-up of total disc replacement compared to fusion: A randomized controlled trial. Eur Spine J 2013;22:2288-95.

Spivak JM, Petrizzo AM. Revision of a lumbar disc arthroplasty following late infection. Eur Spine $J$ 2010;19:677-81.

Stieber JR, Donald GD, 3rd. Early failure of lumbar disc replacement: Case report and review of the literature. J Spinal Disord Tech 2006;19:55-60.

Strube P, Hoff EK, Schmidt H, et al. Parameters influencing the outcome after total disc replacement at the lumbosacral junction. Part 2: Distraction and posterior translation lead to clinical failure after a mean follow-up of 5 years. Eur Spine $J$ 2013;22:2279-87.

Takigawa T, Espinoza Orias AA, An HS, et al. Spinal kinematics and facet load transmission after total disc replacement. Spine 2010;35:E1160-6.

Taksali S, Grauer JN, Vaccaro AR. Material considerations for intervertebral disc replacement implants. Spine J 2004;4:231S-8S.

Thavaneswaran P, Vandepeer M. Lumbar artificial intervertebral disc replacement: A systematic review. ANZ J Surg 2014;84:121-7.

Tortolani PJ, Cunningham BW, Eng M, et al. Preva- lence of heterotopic ossification following total disc replacement. A prospective, randomized study of two hundred and seventy-six patients. J Bone Joint Surg Am 2007;89:82-8.

Tropiano P, Huang RC, Girardi FP, et al. Lumbar total disc replacement. Seven to eleven-year follow-up. J Bone Joint Surg Am 2005;87:490-6.

Van de Kelft E, Verguts L. Clinical outcome of mono segmental total disc replacement for lumbar disc disease with ball in socket prosthesis (Maverick(r)): Prospective study with 4 year follow-up. World Neurosurg 2012;78:355-63.

van Ooij A, Oner FC, Verbout AJ. Complications of artificial disc replacement: A report of 27 patients with the SB Charite disc. J Spinal Disord Tech 2003;16:369-83.

Veruva SY, Lanman TH, Hanzlik JA, et al. Rare complications of osteolysis and periprosthetic tissue reactions after hybrid and non-hybrid total disc replacement. Eur Spine J in press.

Veruva SY, Lanman TH, Isaza JE, et al. UHMWPE wear debris and tissue reactions are reduced for contemporary designs of lumbar total disc replacements. Clin Orthop Relat Res in press.

Veruva SY, Lanman TH, Isaza JE, et al. UHMWPE wear debris and tissue reactions are reduced for contemporary designs of lumbar total disc replacements. Clin Orthop Relat Res 2015;473:987-98.

Vicars R, Hyde PJ, Brown TD, et al. The effect of anterior-posterior shear load on the wear of ProDisc1 tdr. Eur Spine J 2010;19:1356-62.

Vicars R, Prokopovich P, Brown TD, et al. The effect of anterior-posterior shear on the wear of CHARITE total disc replacement. Spine 2012;37:E528-34.

Vuono-Hawkins M, Langrana NA, Parsons JR, et al. Materials and design concepts for an intervertebral disc spacer. II. Multidurometer composite design. $J$ Appl Biomater 1995;6:117-23. 
Wang BH, Campbell G. Formulations of polyvinyl alcohol cryogel that mimic the biomechanical properties of soft tissues in the natural lumbar intervertebral disc. Spine 2009;34:2745-53.

Wang JC, Arnold PM, Hermsmeyer JT, et al. Do lumbar motion preserving devices reduce the risk of adjacent segment pathology compared with fusion surgery? A systematic review. Spine 2012;37:S133-43.

Wang W, Zhang H, Sadeghipour K, et al. Effect of posterolateral disc replacement on kinematics and stress distribution in the lumbar spine: A finite element study. Med Eng Phys 2013;35:357-64.

Warachit P. Results of Charite artificial lumbar disc replacement: Experience in 43 Thais. J Med Assoc Thai 2008;91:1212-7.

Wei HW, Chiang YF, Chen YW, et al. The effects of different articulate curvature of artificial disc on loading distribution. J Appl Biomater Function Mater 2012;10:107-12.

Wei J, Song Y, Sun L, et al. Comparison of artificial total disc replacement versus fusion for lumbar degenerative disc disease: A meta-analysis of randomized controlled trials. Int Orthop 2013;37:1315-25.

Wenzel SA, Shepherd DE. Contact stresses in lumbar total disc arthroplasty. Biomed Mater Eng 2007;17:169-73.

Wininger KL, Deshpande KK, Bester ML. Persistent pain following lumbar disc replacement. Radiol Technol 2012;83:430-6.

Wong DA, Annesser B, Birney T, et al. Incidence of contraindications to total disc arthroplasty: A retrospective review of 100 consecutive fusion patients with a specific analysis of facet arthrosis. Spine $J$ 2007;7:5-11.

Yue J, Zhang K, Bai HX, et al. A comparison of 1-level versus 2-level Prodisc arthroplasty patients: A prospective study with minimum of 5-year follow-up. Spine 2013;38:1194-8.
Yue JJ, Mo FF. Clinical study to evaluate the safety and effectiveness of the Aesculap Activ-L artificial disc in the treatment of degenerative disc disease. BMC Surg 2010;10:14.

Yue JJ, Oetgen ME, Jaramillo-de la Torre JJ, et al. Does vertebral endplate morphology influence outcomes in lumbar disc arthroplasty? Part I: An initial assessment of a novel classification system of lumbar endplate morphology. $S A S J$ 2008;2:16-22.

Zairi F, Remacle JM, Allaoui M, et al. Delayed hypersensitivity reaction caused by metal-on-metal total disc replacement. J Neurosurg Spine

2013;19:389-91.

Zander T, Rohlmann A, Bergmann G. Influence of different artificial disc kinematics on spine biomechanics. Clin Biomech (Bristol, Avon) 2009;24:135-42.

Zeegers WS, Bohnen LM, Laaper M, et al. Artificial disc replacement with the modular type sb Charite III: 2-year results in 50 prospectively studied patients. Eur Spine J 1999;8:210-7.

Zeh A, Becker C, Planert M, et al. Time-dependent release of cobalt and chromium ions into the serum following implantation of the metal-on-metal Maverick type artificial lumbar disc (medtronic sofamor danek). Arch Orthop Trauma Surg 2009;129:741-6.

Zeh A, Planert M, Siegert G, et al. Release of cobalt and chromium ions into the serum following implantation of the metal-on-metal Maverick-type artificial lumbar disc (medtronic sofamor danek). Spine 2007;32:348-52.

Zeilstra D, Oosterhuis W. Anterior lumbar discectomy and disc replacement. Eur Spine J 2011;20:991-2.

Zhong ZC, Chen SH, Hung CH. Load- and displacement-controlled finite element analyses on fusion and non-fusion spinal implants. Proc Inst Mech Eng H 2009;223:143-57.

Zhong ZC, Hung C, Lin HM, et al. The influence of different magnitudes and methods of applying preload on fusion and disc replacement constructs in the 
lumbar spine: A finite element analysis. Comput Methods Biomech Biomed Engin 2013;16:943-53.

Zhu Q, Itshayek E, Jones CF, et al. Kinematic evaluation of one- and two-level Maverick lumbar total disc replacement caudal to a long thoracolumbar spinal fusion. Eur Spine J 2012;21:599-611.

Zigler J, Delamarter R, Spivak JM, et al. Results of the prospective, randomized, multicenter Food and Drug Administration Investigational Device Exemption study of the ProDisc-L total disc replacement versus circumferential fusion for the treatment of 1-level degenerative disc disease. Spine 2007;32:1155-62.

Zigler J, Ohnmeiss DD. Comparison of 2-level versus 1-level total disc replacement: Results from a prospective FDA-regulated trial. $S A S J$ 2008;2:140-4.

Zigler JE, Delamarter RB. Five-year results of the prospective, randomized, multicenter, Food and Drug Administration investigational device exemption study of the ProDisc-L total disc replacement versus circumferential arthrodesis for the treatment of single-level degenerative disc disease. J Neurosurg Spine 2012;17:493-501.

Zigler JE, Glenn J, Delamarter RB. Five-year adjacent-level degenerative changes in patients with single-level disease treated using lumbar total disc replacement with ProDisc-L versus circumferential fusion. J Neurosurg Spine 2012;17:504-11.
Zindrick MR, Tzermiadianos MN, Voronov LI, et al. An evidence-based medicine approach in determining factors that may affect outcome in lumbar total disc replacement. Spine 2008;33:1262-9.

Zweig T, Aghayev E, Melloh M, et al. Influence of preoperative leg pain and radiculopathy on outcomes in mono-segmental lumbar total disc replacement: Results from a nationwide registry. Eur Spine $J$ 2012;21:S729-S36.

Zweig T, Hemmeler C, Aghayev E, et al. Influence of preoperative nucleus pulposus status and radiculopathy on outcomes in mono-segmental lumbar total disc replacement: Results from a nationwide registry. BMC Musculoskelet Disord 2011;12:275.

\section{Disclosures}

Jack Zigler receives consulting fees from DePuy Synthes. Rolando Garcia receives royalties and consulting fees from Aesculap.

\section{Corresponding Author}

Dr. Jack Zigler, Texas Back Institute, 6020 W. Parker Road, Suite 200, Plano TX 75093.

jzigler@texasback.com

Published 12 March 2015.

This manuscript is generously published free of charge by ISASS, the International Society for the Advancement of Spine Surgery. Copyright @ 2015 ISASS. To see more or order reprints or permissions, see http://ijssurgery.com. 